\title{
Kinetic-Spectrophotometric Determination of Iodide Based on its Inhibitory Effect on the Decolorization Reaction of Methyl Orange
}

\author{
REYHANEH RAHNAMA KOZANI ${ }^{*}$,FERYDOUN ASHRAFI, \\ MASUOD KHALILNEZHAD and MOHAMMAD REZA JAMALI ${ }^{\S}$ \\ Department of Chemistry, Payam Noor University, Sari, Iran. \\ ${ }^{\S}$ Department of Chemistry, Payam Noor University, Behshahr, Iran. \\ r_rahnama@mpnu.ac.ir
}

Received 28 January 2009; Accepted 18 March 2009

\begin{abstract}
A simple, sensitive, rapid and reliable method has been developed for spectrophotometric determination of iodide based on its inhibition effect on the redox reaction between bromate and hydrochloric acid. The decolorization of methyl orange by the reaction products was used to monitor the reaction spectrophotometrically at $525 \mathrm{~nm}$. The variables affecting the rate of the reaction were investigated. Under the optimum conditions, the limit of detection is $1.5 \times 10^{-7} \mathrm{~mol} \mathrm{~L}^{-1}$ and calibration range is $2.0 \times 10^{-6}-1.3 \times 10^{-4} \mathrm{~mol} \mathrm{~L}^{-1}$ of iodide. The linearity range of the calibration graph is depends on bromate concentration. The relative standard deviation of ten-replication determination of $8.2 \times 10^{-5} \mathrm{~mol} \mathrm{~L}^{-1}$ iodide was $1.4 \%$. The proposed method was applied to the determination of iodide in natural water samples with satisfactory results.
\end{abstract}

Keywords: Iodide, Bromate, Methyl orange, Inhibition, Spectrophotometric determination.

\section{Introduction}

Iodine is an essential element for human beings. It is a part of the thyroid hormones that plays an important role in the development of brain function and cell growth. Iodine deficiency causes serious delays in neurological development. Not only a lack of iodine (< $140-160 \mu \mathrm{g} /$ day for adults) but also excessive iodine (>20 mg/day) in the diet may cause many disorders, including endemic goiter and hypothyroidism ${ }^{1}$. Populations suffering from iodine deficiency should be supported by more iodine, such as in the form of iodized salt, iodized oil and iodized bread. People and some older people who consume excess iodine suffer from thyroid disease who should consume no iodine and these should avoid excess iodine in their diet. That is why the iodine concentration range in the diet is very important for public health ${ }^{2}$. Therefore, it is necessary to establish sensitive and accurate analytical methods for quantitative determination of iodine. 
Several methods of iodine determination have been proposed, including selective electrodes ${ }^{3}$, spectrophotometry ${ }^{4,5}$, chemiluminescece ${ }^{6}$, electrochemistry ${ }^{7,8}$, atomic absorption spectroscopy $(\mathrm{AAS})^{9}$, chromatography ${ }^{10-12}, \mathrm{X}$-ray fluorescence $(\mathrm{XRF})^{13}$ and inductively coupled plasma mass spectrometry (ICP-MS) ${ }^{14-15}$. Some of these methods are time consuming and suffer from lack of selectivity or good sensitivity and/or have short linear dynamic range or have higher limit of detection and/or used reagents not commercially available. Iodine has also been determined by kinetic methods. Most of the kinetic methods are based on the catalytic effect of iodide on oxidation $^{4,5,16-19}$ and some of them are based on inhibitory effect of iodide on reactions ${ }^{20}$. The kinetic method has many merits, for example, high sensitivity, good selectivity and simple experimental procedures. Besides, the method is easy to follow without expensive apparatus.

In the present paper, a new inhibition kinetic method for the determination of trace iodide has been proposed. It is based on its inhibition effect on the reaction of bromate with hydrochloric acid. The method is very rapid, simple, sensitive, and accurate. Iodide as low as $2.0 \times 10^{-6} \mathrm{~mol} \mathrm{~L}^{-1}$ could be determined by this method in water samples.

\section{Experimental}

All reagents used were of analytical grade. A stock solution of iodide ions was prepared by dissolving appropriate amounts of KI (Merck) in doubly distilled water. Working solutions were prepared from the stock solution by serial dilutions with doubly distilled water. Other reagents used were: methyl orange (Merck), $\mathrm{KBrO}_{3}$ (Merck) and hydrochloric acid (Merck). The pipettes and vessels used for trace analysis were kept in 10\% nitric acid solution for 24 $\mathrm{h}$ and were subsequently washed four times with distilled water.

A Cintra 20 GBC spectrophotometer with two matched $1 \mathrm{~cm}$ quartz cells was used. A thermostat water bath (Behdad, serological water bath) was used to keep the temperature of solutions at $25 \pm 0.1{ }^{\circ} \mathrm{C}$.

\section{Recommended procedure}

All the solutions were equilibrated at $25 \pm 0.1{ }^{\circ} \mathrm{C}$ before the beginning of the reaction. The inhibited reaction was followed spectrophotometrically by monitoring the change in absorbance at $525 \mathrm{~nm}$. A suitable aliquot of sample solution containing iodide was transferred into a $10-\mathrm{mL}$ volumetric flask, and then $1.4 \mathrm{~mL}$ of $2.5 \mathrm{~mol} \mathrm{~L}^{-1} \mathrm{HCl}$ solution was added, followed by $1.0 \mathrm{~mL}$ of $100 \mathrm{mg} \mathrm{L}^{-1}$ methyl orange solution. The solution was diluted to $9 \mathrm{~mL}$ with water and then $0.5 \mathrm{~mL}$ of $1.3 \times 10^{-2} \mathrm{~mol} \mathrm{~L}^{-1}$ bromate solution was added. The stop clock was started just after the addition of bromate solution. The solution was diluted to the mark with water and a portion was transferred to a glass cell within $25 \mathrm{~s}$ for measurement of the variation in absorbance with time at $525 \mathrm{~nm}$.

\section{Results and Discussion}

Bromate can be reduced by hydrochloric acid as follows:

$$
10 \mathrm{Cl}^{-}+2 \mathrm{BrO}_{3}^{-}+12 \mathrm{H}^{+} \rightarrow 5 \mathrm{Cl}_{2}+\mathrm{Br}_{2}+6 \mathrm{H}_{2} \mathrm{O}
$$

The produced bromine and chlorine react with methyl orange and this reaction causes decolorization of methyl orange ${ }^{21}$ as in the following reaction:

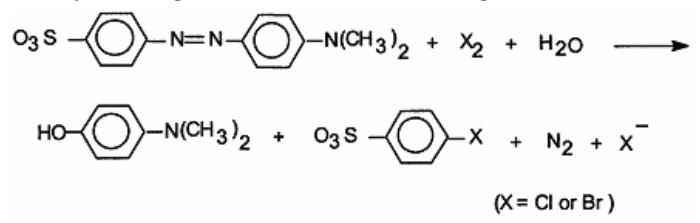


This system has been used for determination of hydrazine ${ }^{22}$, arsenic ${ }^{23}$, ascorbic acide ${ }^{24}$ and thiocyanate ${ }^{25}$. This reaction can be monitored spectrophotometrically by measuring the decrease in absorbance of the reaction mixture at $525 \mathrm{~nm}$ at $25{ }^{\circ} \mathrm{C}$. Iodide ions can react with the product of the reaction (bromine and chlorine); therefore, the induction period increases with increasing iodide concentration (Figure 1). This inhibitory effect on the reaction system depends on the concentration of iodide. The induction period can be measured mathematically from the regression equations of the linear part of the absorption time graph. The regression equation for the first linear part of the graph is:

and for the second linear part is:

$$
A=a_{1}+b_{1} t
$$

$$
A=a_{2}+b_{2} t
$$

By equating these equations the induction period can be calculated as:

$$
t_{\text {ip }}=a_{1}-a_{2} / b_{2}-b_{1}
$$

Therefore, the calibration graph can be prepared by plotting $t_{\mathrm{ip}}$ versus iodide concentration.

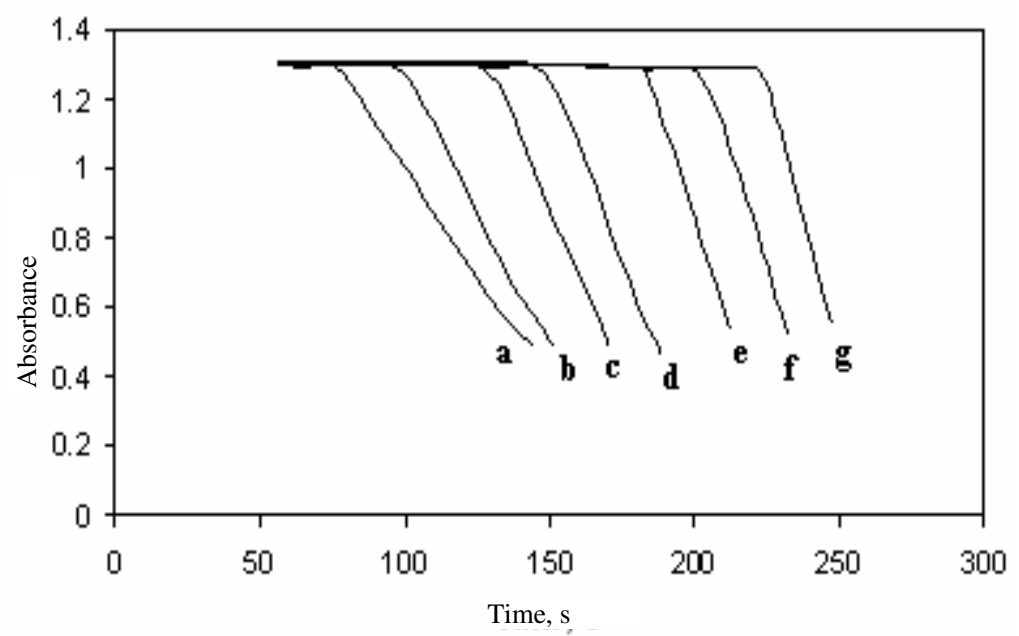

Figure 1. Change in absorbance of $10 \mathrm{mg} \mathrm{L}^{-1}$ methyl orange solution over time in the presence of $6.5 \times 10^{-4} \mathrm{~mol} \mathrm{~L}^{-1}$ bromate, $0.35 \mathrm{~mol} \mathrm{~L}^{-1} \mathrm{HCl}$ and (a) $3.3 \times 10^{-5}$; (b) $4.9 \times 10^{-5}$; (c) $6.6 \times 10^{-5}$; (d) $8.2 \times 10^{-5}$; (e) $9.9 \times 10^{-5}$; (f) $1.1 \times 10^{-4}$; (g) $1.3 \times 10^{-4} \mathrm{~mol} \mathrm{~L}^{-1}$ iodide.

\section{Effect of variables}

To take full advantage of the procedure, the reagent concentrations and reaction conditions must be optimized. Various experimental parameters were studied in order to obtain the optimized system. These parameters were optimized by setting all parameters to be constant and optimizing one each time.

The influence of hydrochloric acid concentration on the sensitivity was studied over the range of $0.20-0.40 \mathrm{~mol} \mathrm{~L}^{-1}$. In order to find the optimum concentration of hydrochloric acid, the absorbance changes for the blank reaction (the reaction in the absence of iodide) and the sample reaction (the reaction in the presence of iodide) at a fixed time of $60 \mathrm{~s}$ were measured as a function of $\mathrm{HC1}$ concentration. The results are shown in Figure 2. The difference between the absorbance change for the blank reaction and sample reaction shows a maximum at $0.35 \mathrm{~mol} \mathrm{~L}^{-1} \mathrm{HC}$. Therefore, a final concentration of $0.35 \mathrm{~mol} \mathrm{~L}^{-1}$ acid was selected as optimum. 


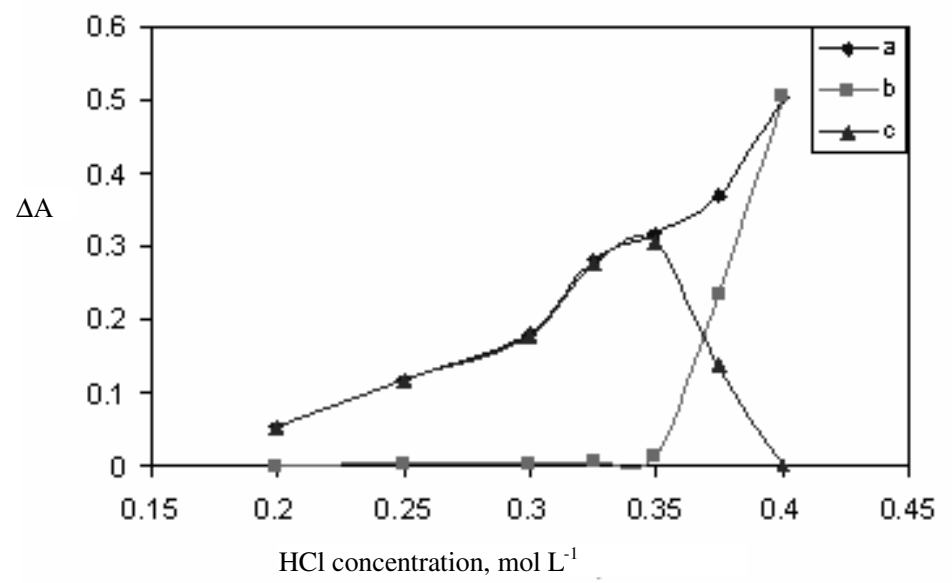

Figure 2. Absorbance change for (a) blank, (b) sample reaction and (c) their difference as a function of $\mathrm{HCl}$ concentration, conditions: bromate, $6.5 \times 10^{-4} \mathrm{~mol} \mathrm{~L}^{-1}$; iodide, $7.9 \times 10^{-5} \mathrm{~mol} \mathrm{~L}^{-1}$; methyl orange, $10 \mathrm{mg} \mathrm{L}^{-1} ; t=60 \mathrm{~s}$.

The effect of bromate concentration in the range of $3.9 \times 10^{-4}-1.0 \times 10^{-3} \mathrm{~mol} \mathrm{~L}^{-1}$ was investigated. As Figure 3 shows, an increase in bromate concentration caused a decrease in the induction period and an increase in the slope of the absorbance change after initiation of the reaction. It was also observed that the calibration range differed according to the concentration of bromate and hence the concentration of bromate must be selected on this basis (Table 1). The rate of the reaction of bromate with $\mathrm{HCl}$ and therefore the rate of production of $\mathrm{Cl}_{2}$ and $\mathrm{Br}_{2}$ increases by increasing $\mathrm{HCl}$ and/or bromate concentration. This causes an increase in the rate of the reaction of $\mathrm{Cl}_{2}$ and $\mathrm{Br}_{2}$ with iodide and therefore decreases the induction period. An increase in the production rate of $\mathrm{Cl}_{2}$ and $\mathrm{Br}_{2}$ also causes an increase in the rate of their reaction with methyl orange and therefore the slope of the absorbance change after initiation of the reaction.

Table 1. Linear regression parameters of calibration data for different concentrations of bromate

\begin{tabular}{ccccc}
\hline $\begin{array}{c}{\left[\mathrm{BrO}_{3}^{-}\right]} \\
\mathrm{mol} \mathrm{L}^{-1}\end{array}$ & $\begin{array}{c}\text { Slope } \\
\text { sL mol }\end{array}$ & $\begin{array}{c}\text { Intercept } \\
(\mathrm{s})\end{array}$ & $\begin{array}{c}\text { Correlation } \\
\text { coefficient }\end{array}$ & $\begin{array}{c}\text { Calibration range, } \\
\mathrm{mol} \mathrm{L}^{-1}\end{array}$ \\
\hline $3.2 \times 10^{-4}$ & $2.0 \times 10^{6}$ & 28.2 & 0.9950 & $3.3 \times 10^{-5}-1.3 \times 10^{-4}$ \\
$6.5 \times 10^{-5}$ & $2.0 \times 10^{7}$ & 32.3 & 0.9980 & $2.0 \times 10^{-6}-2.3 \times 10^{-5}$ \\
\hline
\end{tabular}

The influence of methyl orange concentration on the sensitivity was studied in the presence of $0.35 \mathrm{~mol} \mathrm{~L}^{-1} \mathrm{HCl}$ and $6.5 \times 10^{-4} \mathrm{~mol} \mathrm{~L}^{-1}$ bromate concentration at $25^{\circ} \mathrm{C}$ with and without addition of iodide. The results showed that methyl orange concentration in the range of $5-15 \mathrm{mg} \mathrm{L}^{-1}$ had no effect on the sample or blank reaction. Therefore, a concentration of $10 \mathrm{mg} \mathrm{L}^{-1}$ methyl orange was used for routine work.

The influence of temperature on the sensitivity was studied over the temperature range of 4-30 ${ }^{\circ} \mathrm{C}$ in the optimum conditions. The results are shown in Figure 4. As the figure shows by increasing temperature up to $25{ }^{\circ} \mathrm{C}$ the sensitivity increased, and after that the sensitivity decreased. Therefore, $25^{\circ} \mathrm{C}$ was selected for the study.

Ionic strength had no effect on the rate of both reactions up to $1.0 \mathrm{~mol} \mathrm{~L}^{-1} \mathrm{KNO}_{3}$; this is an advantage in the determination of iodide in real samples. 


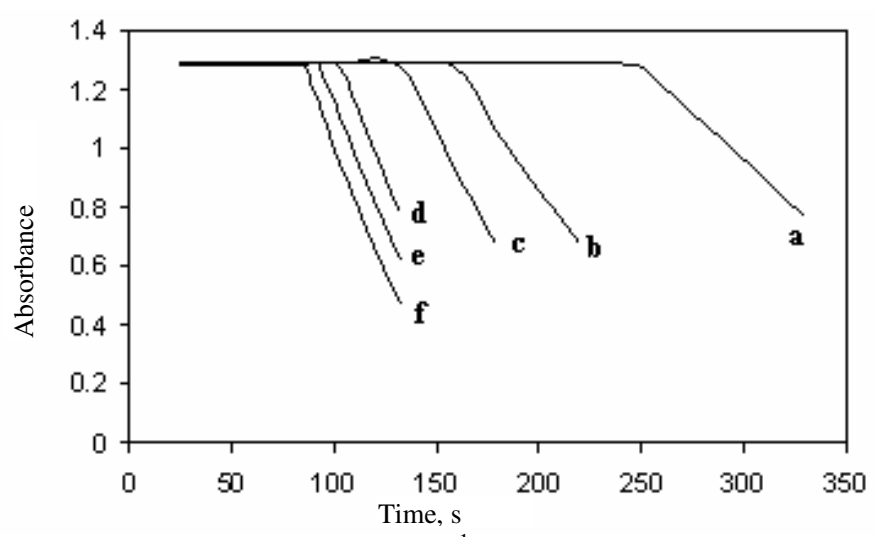

Figure 3. Change in absorbance of $10 \mathrm{mg} \mathrm{L}^{-1}$ methyl orange solution over time in the presence of $0.35 \mathrm{~mol} \mathrm{~L}^{-1} \mathrm{HCl}, 7.9 \times 10^{-5} \mathrm{~mol} \mathrm{~L}^{-1}$ iodide and (a) $3.9 \times 10^{-4}$; (b) $5.2 \times 10^{-4}$; (c) $6.5 \times 10^{-4}$; (d) $7.8 \times 10^{-4}$; (e) $9.1 \times 10^{-4}$; (f) $1.0 \times 10^{-3} \mathrm{~mol} \mathrm{~L}^{-1}$ bromate.

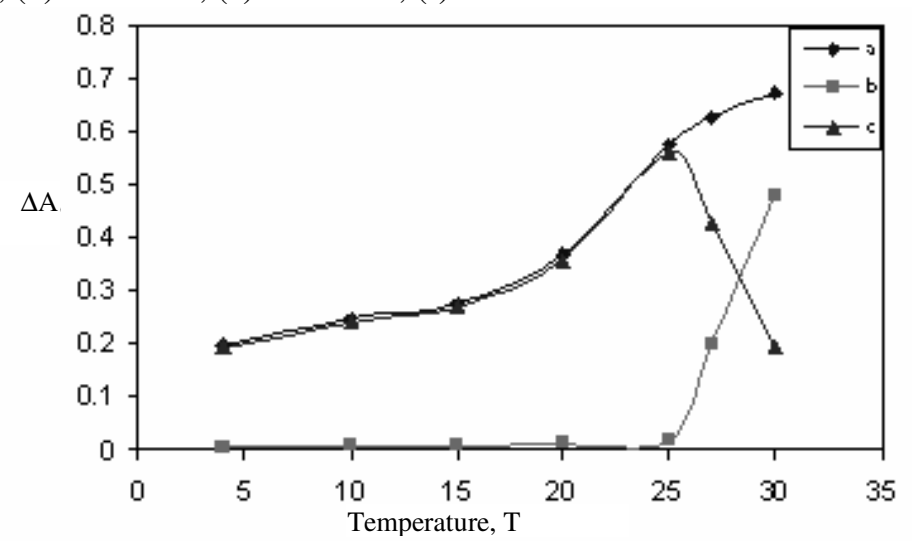

Figure 4. Absorbance change for (a) blank, (b) sample reaction and (c) their difference as a function of temprature, conditions: bromate, $6.5 \times 10^{-4} \mathrm{~mol} \mathrm{~L}^{-1} ; \mathrm{HCl}, 0.35 \mathrm{~mol} \mathrm{~L}^{-1}$; iodide, $7.9 \times 10^{-5} \mathrm{~mol} \mathrm{~L}^{-1}$; methyl orange, $10 \mathrm{mg} \mathrm{L}^{-1} ; t=60 \mathrm{~s}$.

\section{Determination of activation parameters}

The reaction rate of bromate with hydrochloric acid was determined at four different temperatures. A plot of $\ln k$ versus $1 / T$ gives a straight line, from which the energy of activation $\left(\Delta E^{\ddagger}\right.$ or $\left.E a\right)$ is calculated according to the Arrhenius equation:

$$
k=A \cdot e^{-\Delta E \neq / R T}
$$

Where $k$ is the reaction rate constant and $R$ is the gas constant. The other thermodynamic parameters were calculated at $25^{\circ} \mathrm{C}$. Calculation of the enthalpy of activation $\left(\Delta H^{\ddagger}\right)$ was performed using the relation

$$
\Delta E^{\neq}=\Delta H^{\ddagger}+R T
$$

The entropy of activation $\left(\Delta S^{\ddagger}\right)$ was obtained from the Equation (8):

$$
A=K T / h \cdot e^{(R+\Delta S \neq / R)}
$$

where, $K$ and $h$ are rate constant and Planck's constant, respectively.

The free energy of activation $\left(\Delta G^{\#}\right)$ was calculated according to Equation (9):

$$
\Delta G^{\#}=\Delta H^{\ddagger}-T \Delta S^{\ddagger}
$$

The results are listed in Table 2 . 
Table 2. Activation parameters for the decolorization of methyl orange reaction at $25^{\circ} \mathrm{C}$

\begin{tabular}{ccccc}
\hline$A\left(\mathrm{~L}^{3} / \mathrm{mol}^{3} . \mathrm{s}\right)$ & $\Delta E^{\ddagger}(\mathrm{kJ} / \mathrm{mol})$ & $\Delta H^{\ddagger}(\mathrm{kJ} / \mathrm{mol})$ & $\Delta S^{\ddagger}(\mathrm{J} / \mathrm{mol} \mathrm{K})$ & $\Delta G^{\#}(\mathrm{~kJ} / \mathrm{mol})$ \\
\hline $2.6 \times 10^{8}$ & 33.8 & 31.3 & -578.2 & 203.6 \\
\hline
\end{tabular}

\section{Analytical parameters}

Under the optimum conditions a linear correlation was found between the induction period and iodide concentration. The linear dynamic range depends on the bromate concentration and the results are presented in Table 1 . The limit of detection $\left(3 S_{\mathrm{b}} / m\right.$, three of the standard deviation blank divided by slope of the calibration curve) was $1.5 \times 10^{-7} \mathrm{~mol} \mathrm{~L}^{-1}$, iodide. The relative standard deviations for ten-replication determinations of $6.6 \times 10^{-6} \mathrm{~mol} \mathrm{~L}^{-1}$ and $8.2 \times$ $10^{-5} \mathrm{~mol} \mathrm{~L}^{-1}$ iodide were 2.3 and $1.4 \%$ respectively.

\section{Selectivity}

To study the selectivity of the proposed method, the effect of various cations and anions on the determination of $6.6 \times 10^{-5} \mathrm{~mol} \mathrm{~L}^{-1}$ of iodide was studied. Relative errors in induction period $\left(t_{i p}\right)$ of less than $\pm 3 \%$ were considered negligible. The results are given in Table 3 . As can be seen, most of the investigated cations and anions did not interfere even when present in 100fold excess over iodide. Among the investigated ions, $\mathrm{SO}_{3}{ }^{2-}, \mathrm{Fe}^{2+}, \mathrm{Mo}(\mathrm{VI})$ interfered.

Table 3. Tolerance limits for diverse ions on the determination of $6.6 \times 10^{-5} \mathrm{~mol} \mathrm{~L}^{-1}$ iodide.

\begin{tabular}{lc}
\hline \multicolumn{1}{c}{ Ion } & Tolerance limit ratio \\
\hline $\mathrm{K}^{+}, \mathrm{Na}^{+}, \mathrm{Ba}^{2+}, \mathrm{Ca}^{2+}, \mathrm{NH}^{4+}, \mathrm{Mg}^{2+}, \mathrm{Ni}^{2+}, \mathrm{Mn}^{2+}, \mathrm{Cu}^{2+}, \mathrm{Cr}^{3+}$, & \\
$\mathrm{Al}^{3+}, \mathrm{Zn}^{2+}, \mathrm{Co}^{2+}, \mathrm{Cd}^{2+}, \mathrm{Fe}^{3+}, \mathrm{Pb}^{2+}, \mathrm{As}(\mathrm{V}), \mathrm{NO}_{3}^{-}, \mathrm{CH}_{3} \mathrm{COO}^{-}$, & 100 \\
$\mathrm{C}_{2} \mathrm{O}_{4}{ }^{2-}, \mathrm{SO}_{4}^{2-}$ & 50 \\
$\left.\mathrm{Cr}^{2-} \mathrm{VI}\right)$ & 5 \\
$\mathrm{NO}_{2}^{-}$ & 1 \\
$\mathrm{SO}_{3}{ }^{2-}, \mathrm{Fe}^{2+}, \mathrm{Mo}(\mathrm{VI})$ & 1 \\
\hline
\end{tabular}

\section{Analytical Application}

To evaluate the analytical applicability of the proposed method, the method was applied to determination of iodide in various water samples. According to the results, the concentration of iodide in analyzed water samples was below the LOD of the method. The suitability of the proposed method for the analysis of natural water samples was checked by spiking samples with $3.30 \times 10^{-6}$ and $6.60 \times 10^{-6} \mathrm{~mol} \mathrm{~L}^{-1}$ of iodide. Good recoveries $(93.9-107.8 \%)$ were achieved for all analyzed samples. The data obtained with the proposed method were presented in Table 4. The results indicate that this method can be applied for iodide determination in these samples with no serious interference.

Table 4. Determination of iodide in real samples.

\begin{tabular}{|c|c|c|c|}
\hline \multirow{2}{*}{ Sample } & \multicolumn{2}{|c|}{ Iodide, $\mathrm{mol} \mathrm{L}^{-1}$} & \multirow{2}{*}{ Recovery, \% } \\
\hline & Added & Found & \\
\hline \multirow{2}{*}{ River water $1^{a}$} & $3.30 \times 10^{-6}$ & $3.20 \times 10^{-6}$ & 97.0 \\
\hline & $6.60 \times 10^{-6}$ & $6.20 \times 10^{-6}$ & 93.9 \\
\hline \multirow{2}{*}{ River water $2^{b}$} & $3.30 \times 10^{-6}$ & $3.50 \times 10^{-6}$ & 106.0 \\
\hline & $6.60 \times 10^{-6}$ & $7.10 \times 10^{-6}$ & 107.8 \\
\hline \multirow{2}{*}{ Tap water ${ }^{\mathrm{c}}$} & $3.30 \times 10^{-6}$ & $3.28 \times 10^{-6}$ & 99.4 \\
\hline & $6.60 \times 10^{-6}$ & $6.55 \times 10^{-6}$ & 99.2 \\
\hline
\end{tabular}

${ }^{a}$ Haraz river water, Iran; ${ }^{b}$ Tajan river water, Sari, Iran ${ }^{c}$ From drinking water system of Sari, Iran. 


\section{Conclusions}

A simple, sensitive, rapid, lower cost and fairly selective procedure is reported for the determination of iodide by spectrophotometric technique. The proposed method can be used for the determination of ultra trace levels of iodide without use of any preconcentration steps. This is a novel method and is suitable for simple and accurate determination of this element in a variety of water samples with satisfactory results.

\section{Acknowledgement}

The author thanks the research council at the Payam Noor University for financial support.

\section{References}

1. Nordic Nutrition Recommendation, Scand. J Nutr./Noeingsforsking,1996, 40, 161.

2. World Health Organisation (WHO), Trace Elements in Nutrition and Health 1996, 49.

3. Alegret S, Florido A, Lima J L F C and Machado A A S C, Talanta, 1989, 36, 825.

4. Gamallo-Lorenzo D, Barciala-Alonso M C and Moreda-Pineiro A, Anal Chim Acta, 2005, 542, 287.

5. Tesfaldet Z O, Van Staden J F and Stefan R I, Talanta, 2004, 64, 1213.

6. Ratanawimarnwong $\mathrm{N}$, Amornthammarong $\mathrm{N}$, Choengchan $\mathrm{N}$, Chaisuwan $\mathrm{P}$, Amatatongchai M, Wilairat P, McKelvie I D and Nacapricha D, Talanta, 2005, 65, 756.

7. Mo S M, Liang L N, Cai Y Q and Mou S F, J Instrum Anal., (Chin.) 2006, 25, 105.

8. Masadome T, Sonoda R and Asano Y, Talanta, 2000, 52, 1123.

9. Yebra M C and Cespon R M, Anal Chim Acta, 2000, 405, 191.

10. Tucker H L and Flack R W, J Chromatogr. A, 1998, 804, 131.

11. $\quad$ Li R and Takeuchi T, J Chromatogr. A, 2004, 1042, 131.

12. Li H B, Chen F and Xu X R, J Chromatogr. A, 2001, 918, 335.

13. Crecelius E A, Anal Chem., 1975, 47, 2034.

14. Vanhoe H, Van Allemeersch F, Versieck J and Dams R, Analyst, 1993, 118, 1015.

15. Schramel P and Hasse S, Microchim Acta, 1994, 116, 205.

16. Tanaka A, Obata K and Deguchi T, Anal Sci., 1986, 2, 197.

17. Liang B, Kawakubo S, Iwatsuki M and Fukasawa T, Anal Chim Acta, 1993, 282, 87.

18. Weisz H and Rothmaier K, Anal Chim Acta, 1993, 80, 351.

19. Weisz H and Rothmaier K, Anal Chim Acta, 1975, 75, 119.

20. Zhu X and Zhang Y, Spectrochim Acta, Part A, 2008, 70, 510.

21. Boltz D F and Howell J A, Eds., Colorimetric Determination of Nonmetals, Wiley, New York, 1978.

22. Afkhami A and Afshar-E-Asl A, Anal Chim Acta, 2000, 419, 101.

23. Afkhami A, Madrakian T and Afshar-E-Asl A, Talanta, 2001, 55, 55.

24. Ensafi A, Rezaei B and Movahedinia H, Spectrochim Acta, Part A, 2002, 58, 2589.

25. Madrakian T, Esmaeili A and Abdolmaleki A, J Anal Chem., 2004, 59, 28. 


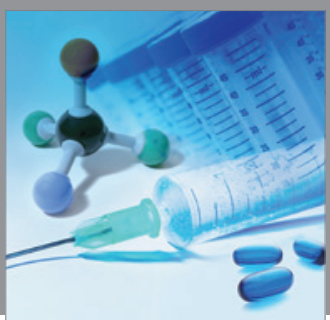

International Journal of

Medicinal Chemistry

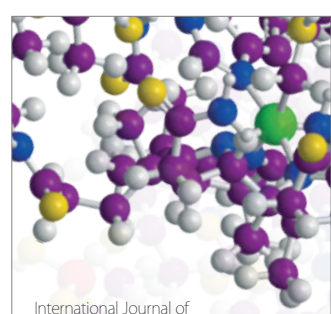

Carbohydrate Chemistry

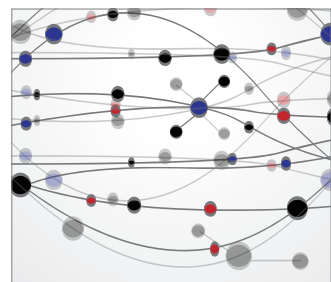

The Scientific World Journal
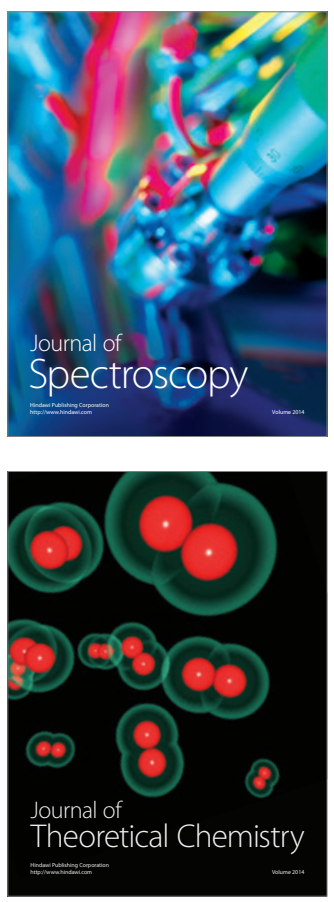
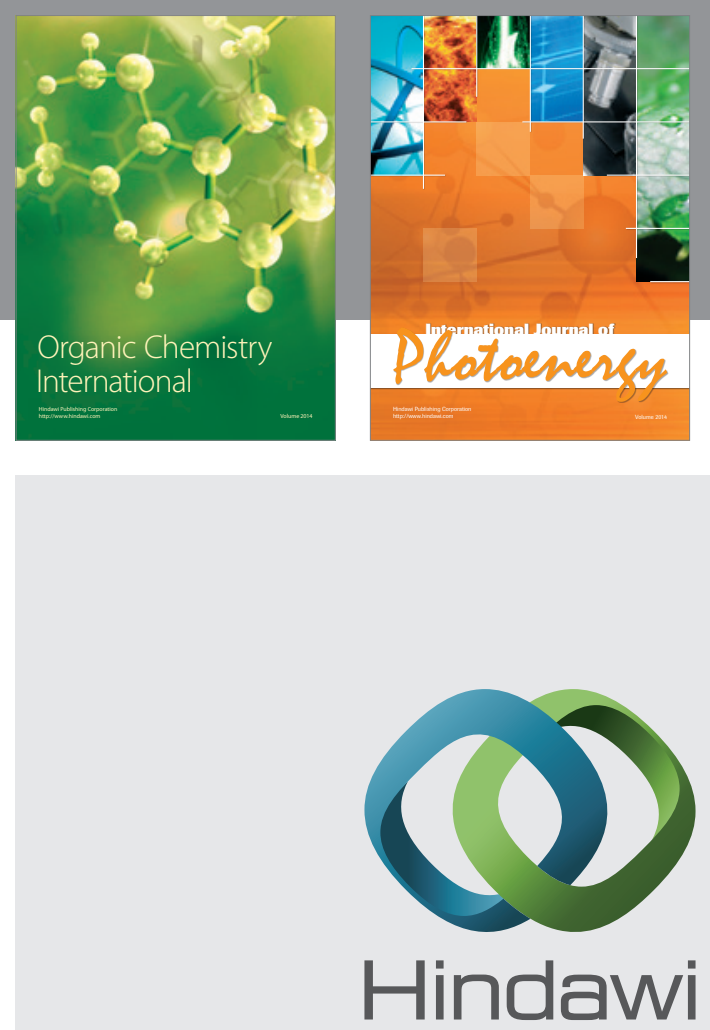

Submit your manuscripts at

http://www.hindawi.com
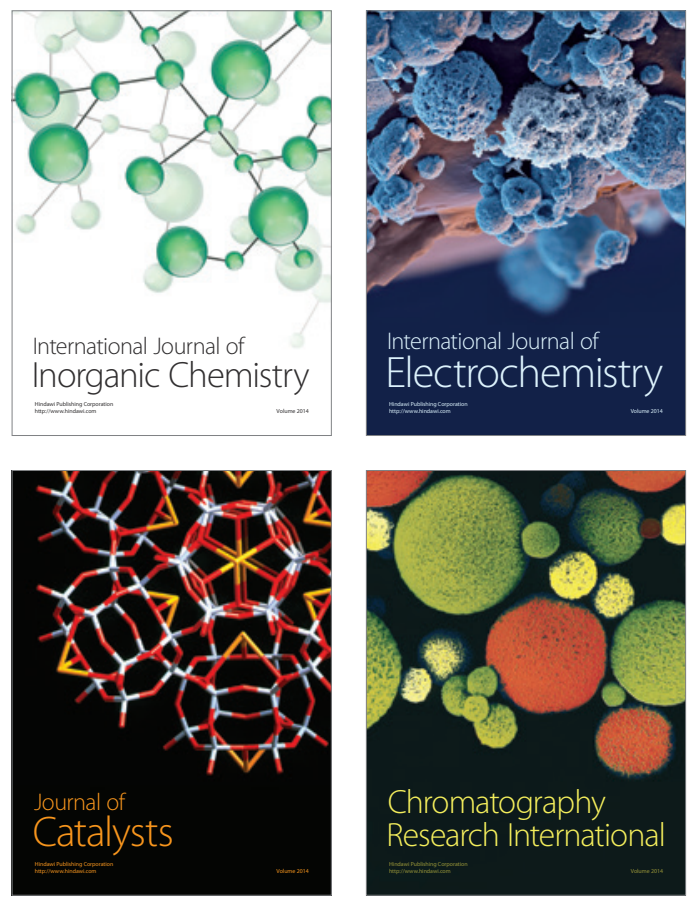
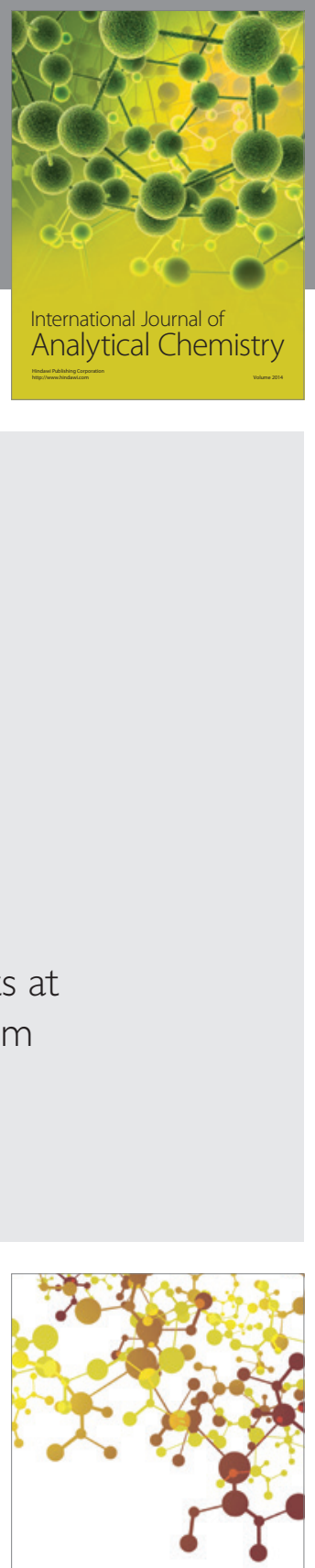

Journal of

Applied Chemistry
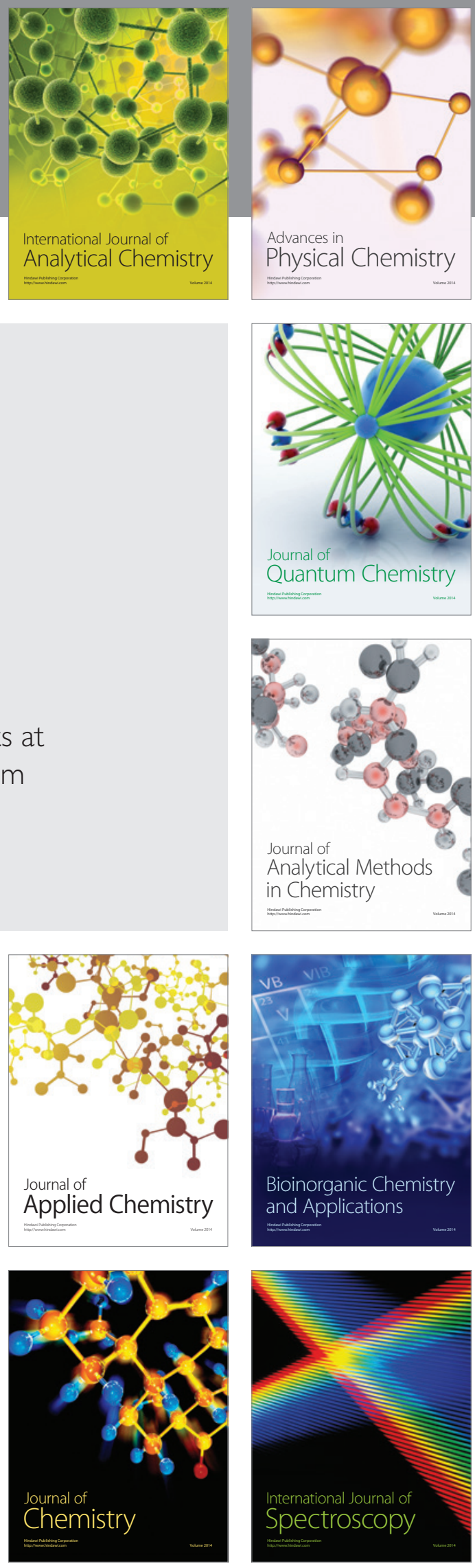